\title{
Comparing Photosynthesis, Growth, and Yield of Paprika (Capsicum annuum L. 'Cupra') under Supplemental Sulfur Plasma and High-Pressure Sodium Lamps in Growth Chambers and Greenhouses
}

\author{
Kyoung Sub Park ${ }^{1 \dagger}$, Dae Young Kwon ${ }^{2 \dagger}$, Joon Woo Lee ${ }^{3}$, and Jung Eek Son ${ }^{3 *}$ \\ ${ }^{1}$ Protected Horticulture Research Institute, National Institute of Horticultural and Herbal Science, Haman 52054, Korea \\ ${ }^{2}$ Cheong-ju Agricultural Technology Center, Cheongju 28806, Korea \\ ${ }^{3}$ Department of Plant Science and Research Institute of Agriculture and Life Sciences, Seoul National University, Seoul 08826, Korea
}

\begin{abstract}
Supplemental lighting with artificial light sources is a practical method that enables normal growth and enhances the yield and quality of fruit vegetable in greenhouses. The objective of this study was to investigate the effect of sulfur plasma lamp (SP) and high-pressure sodium lamp (HPS) as supplemental lighting sources on the growth and yield of paprika. For investigating the effectiveness of SP and HPS lamps on paprika, the effects of primary lighting on plant growth were compared in growth chambers and those of supplemental lighting were also compared in greenhouses. In the growth chamber, plant height, leaf area, stem diameter, number of leaves, fresh weight, and dry weight were measured weekly at SP and HPS from 2 weeks after transplanting. In the greenhouse, no supplemental lighting (only sunlight) was considered as the control. The supplemental lights were turned on when outside radiation became below $100 \mathrm{~W} \cdot \mathrm{m}^{-2}$ from 07:00 to 21:00. From 3 weeks after supplemental lighting, the growth was measured weekly, while the number and weight of paprika fruits measured every two weeks. In the growth chamber, the growth of paprika at SP was better than at HPS due to the higher photosynthetic rate. In the greenhouse, the yield was higher under sunlight with either HPS or SP than sunlight only (control). No significant differences were observed in plant height, number of node, leaf length, and fresh and dry weights between SP and HPS. However, at harvest, the number of fruits rather than the weight of fruits were higher at SP due to the enhancement of fruiting numbers and photosynthesis. SP showed a light spectrum similar to sunlight, but higher PAR and photon flux sum of red and far-red wavelengths than HPS, which increased the photosynthesis and yield of paprika.
\end{abstract}

Additional key words : greenhouse, growth chamber, light spectrum, sunlight, supplemental lighting

\section{Introduction}

Light is an essential energy source that acts as a signal for survival and reproduction for plants. Since $89 \%$ of greenhouse areas rely only on sunlight, the yields and quality of products change according to drastic fluctuations in light intensity and day length with season (Jeong et al., 2009a). Low irradiation can lead to early falling flowers and fruits or irregular fruit settings (Heuvelink and Koner, 2001; Kim et al., 2011). Consequently, the yield and quality of greenhouse crops decrease during winter season in middle-latitude regions such as Korea or high-latitude regions such as the Netherlands. To overcome the low light intensity in winter season, high-pressure sodium lamps

$\dagger$ These authors equally contributed to this work

*Corresponding author: sjeenv@snu.ac.kr

Received October 2, 2018; Revised October 11, 2018;

Accepted October 12, 2018 have been used to compensate the lack of light and to increase the yield of fruit vegetables such as cucumber, tomato, and paprika in Europe (Hao and Paadopoulos, 1999; Aistè at al., 2015; Hao at al., 2016).

In particular, the prevalent cropping season of paprika starts from the end of August and ends in June of the next year in Korea. Therefore, low light conditions from October to February induce longer harvest days after fruit setting, lower fruit setting rates, and higher incidence of malformed fruits at longer cloudy days. Since the fruit setting rate of paprika is susceptible to the change in the amount of light when light intensity widely fluctuates (as in Korea), low irradiation decreases productivity of paprika (Jeong et al., 2009b). Many studies indicated that supplemental lightings improved the productivity and quality of crops (Hogewoning et al., 2010a, 2010b; de Visser et al., 2014; Cocetta et al., 2017). Particularly in fruit vegetables, such as tomato, cucumber, and paprika supplemental lighting can be an essential method for compensating the defi- 
Comparing Photosynthesis, Growth, and Yield of Paprika (Capsicum annuum L. 'Cupra') under Supplemental Sulfur Plasma...

cit of sunlight (Kim et al., 2011; de Visser et al., 2014; Hernández and Kubota, 2014; Guo et al., 2016b). Recently, various supplemental lights, such as light-emitting diode and high-pressure sodium lamp, have been used for greenhouse crop production (Gomez et al., 2013; Kim et al., 2013; Lee et al., 2014). Because individual wavelengths differently affect the production and quality of fruits $(\mathrm{Li}$ and Kubota, 2009; Hogewoning et al., 2010b; Hikosaka et al., 2013; Guo et al., 2016a; Hao et al., 2016; Yang et al., 2017), it is important to choose appropriate light sources for crop production.

For greenhouse cultivation, numerous studies have focused on the enhancement effects of supplemental lighting on the productivity and quality of fruits at low-light seasons. However, high-pressure sodium lamps have been mostly used due to the high efficiency of PAR spectrum (400-700nm) in greenhouse and the low cost (Dorais et al., 1991; Demers et al., 1998), while LED was often applied to intra-canopy lighting due to its low output (Trouwborst et al., 2009; Gomez et al., 2013). Hogewoning (2010a) reported that an artificial solar lamp using plasma lamp which closely resembles sunlight spectrum showed higher growth in cucumbers. As artificial lamps with a light spectrum similar to sunlight, plasma lamps were used for cucumbers and tomatoes at seedling and vegetative stages in greenhouses (Hogewoning et al., 2012). Therefore, plasma lamps should be applied to other crops except cucumber until harvest stage for evaluation of its effectiveness. The objective of this study was to compare the supplemental lighting effects of sulfur plasma and high pressure sodium lamps on the growth, productivity, and physiological characteristics of paprika in growth chamber and greenhouse.

\section{Materials and Methods}

\section{Plant and Cultivation Conditions}

Seeds of paprika (Capsicum annuum L. 'Cupra') were sown on 25 September, 2015 and transplanted on 8 December, 2015 for greenhouse experiment and were sown on 27 March, 2016 and transplanted on 21 April, 2016 for growth chamber experiment. Nutrient solutions were maintained at an electrical conductivity of $2.5 \sim 3.0 \mathrm{dS} \cdot \mathrm{m}^{-1}$, a pH of $5.8 \sim$ 6.0 , and an air temperatures of $25^{\circ} \mathrm{C} / 18^{\circ} \mathrm{C}$ (day/night) with ventilation and heating in greenhouses. Nutrient solutions of Dutch PBG were composed as N 12.75, P 3.75, K 6.0, Ca 7.5 , and $\mathrm{Mg} 2.5 \mathrm{mg} \cdot \mathrm{L}^{-1}$. The experiment was conducted in a
Venlo-type greenhouse and growth chambers at National Institute of Horticultural and Herbal Science of Rural Development Administration (RDA) located at Haman, Korea.

\section{Spectral Characteristics of Supplemental Lights}

A $1000 \mathrm{~W}$ high-pressure sodium lamp (HPS; E-papillon $1000 \mathrm{~W}$, Light Interaction, Eindhoven, Netherland) and $1030 \mathrm{~W}$ sulfur plasma lamp (SP; SPLS-1000, LG Electronics, Seoul, Korea) were used as supplemental light sources. Portions of ultraviolet (UV, 300-400 nm), photosynthetic photon flux density (PPFD, 400-700 nm), and near infrared (NIR, 700-1100 nm) lights in HPS and SP were measured at the vertical distance of $4 \mathrm{~m}$ from the light sources by using a radio spectrometer (Li-1800, Li-COR, Lincoln, NE, USA). R/FR ratio was obtained by dividing the portion of red light $(655-665 \mathrm{~nm})$ to far-red light $(725-735 \mathrm{~nm})$ by Smith's definition (1982).

\section{Growth Index and Photosynthesis at HPS and SP}

\section{in Growth Chamber}

To identify the effect of HPS and SP on paprika growth and development, cultivation experiments were conducted in two growth chambers ( $\mathrm{L} 1.6 \mathrm{~m} \times \mathrm{W} 1.4 \mathrm{~m} \times \mathrm{H} 1.8 \mathrm{~m}$, DS-59M, Dasol, Hwaseong, Korea) with each two HPSs and two SPs at a photoperiod of $14 \mathrm{~h} / 10 \mathrm{~h}$ (day/night), respectively. Air temperature and relative humidity were maintained at $25^{\circ} \mathrm{C}$ and $50 \%$ during the day and at $18^{\circ} \mathrm{C}$ and $50 \%$ at night, respectively. The maximum leaf length, plant height, number of nodes, diameter of stem, SPAD, and leaf area were measured on 27 June, 2016; in addition, fresh and dry weights were measured every two weeks. At 8 weeks after transplanting in the growth chamber, photosynthetic rates and leaf temperature were measured by using a photosynthesis measuring apparatus (Li-6400, LiCOR, Lincoln, NE, USA). The temperature and relative humidity in the leaf chamber were maintained at $25^{\circ} \mathrm{C}$ and $45-55 \%$, respectively. Net $\mathrm{CO}_{2}$ assimilation rate as a function of light curves was determined at each step every 3-4 min. Variable PPFDs were beamed from an internal LED light source ranging from 0 to $1500 \mu \mathrm{mol} \cdot \mathrm{m}^{-2} \cdot \mathrm{s}^{-1}$ at a $\mathrm{CO}_{2}$ concentration of $400 \mu \mathrm{mol} \cdot \mathrm{mol}^{-1}$.

\section{Growth Index under Supplemental Lights in Greenhouses}

The greenhouses $(\mathrm{W} 9.6 \mathrm{~m} \times \mathrm{L} 45 \mathrm{~m} \times \mathrm{H} 5.5 \mathrm{~m}$ ) were divided to three plots for comparative experiments: with 


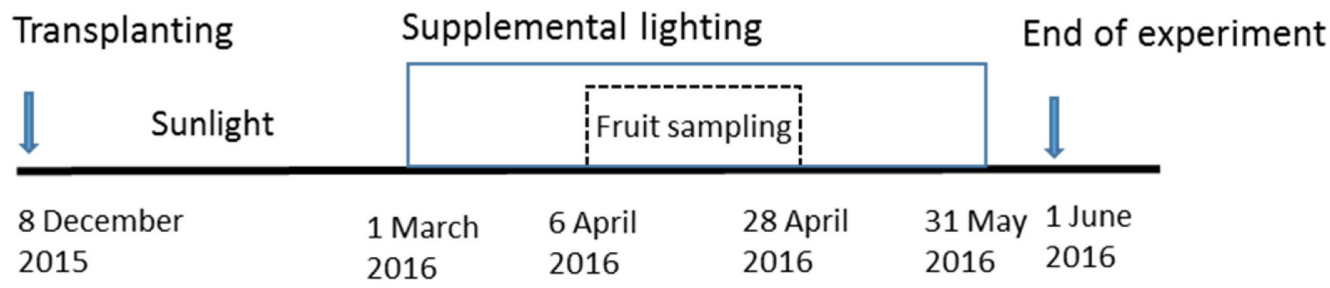

Fig. 1. Cultivation of paprika and supplemental lighting schedules in greenhouse.

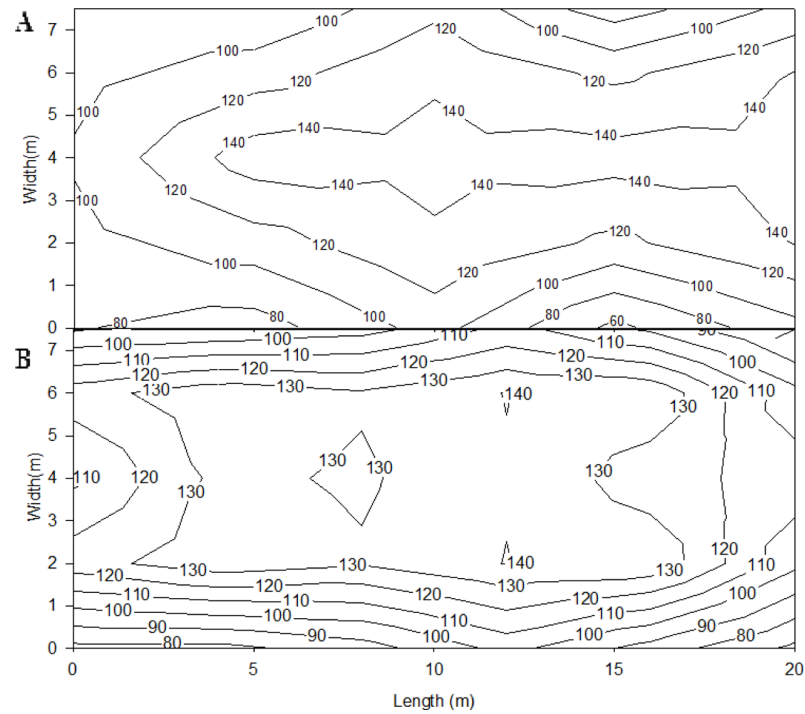

Fig. 2. Distributions of photosynthetic photon flux density $\left(\mu \mathrm{mol} \cdot \mathrm{m}^{-2} \cdot \mathrm{s}^{-1}\right)$ at the floor of the greenhouses where high pressure sodium lamp (A) and sulfur plasma lamp (B) were installed.

the sunlight with two supplemental lighting treatments of Sun + HPS and Sun + SP, and the sunlight without supplemental lighting (Sun). Supplemental lighting started from 1 March to 31 May, 2016 and fruits were sampled from 6 April to 28 April, 2016 in order to reflect the pure effect of supplemental lighting (Fig. 1). From 07:00 to 21:00, the supplemental lights installed at the height of $4 \mathrm{~m}$ from the ground turned on when outside solar radiation was below $104.2 \mathrm{~W} \cdot \mathrm{m}^{-2}$ (in the average of $10 \mathrm{~min}$ ) until 1 June, 2016. From 07:00 to 21:00 in a day, supplemental lights in the greenhouses turned on for about 3 hours a day ( 1 hour in the morning and 2 hours in the evening) on a sunny day and about 14 hours a day on a rainy or cloudy day under the outer irradiation of $100 \mathrm{~W} \cdot \mathrm{m}^{-2}$.

In order to make the same PPFD, eighteen SPs were installed at an interval of $3 \mathrm{~m} \times 3 \mathrm{~m}$ and fifteen of HPSs were installed at an interval of $3 \mathrm{~m} \times 4 \mathrm{~m}$. The PPFDs at the floor (15 areas) under lamps were measured at night by using a quantum sensor (Li-250A, Li-COR, Lincoln, NE,
USA). The average PPFDs were 113.1 and $112.1 \mu \mathrm{mol} \cdot \mathrm{m}^{-2} \cdot \mathrm{s}^{-1}$ at HPS and SP, respectively (Fig. 2). To assess the difference in light environment in the greenhouses under supplemental lights, the light spectra were measured at Sun, Sun + HPS, and Sun + SP in the greenhouses on a clear day and a cloudy day by using the radio spectrometer. The number and weight of fruits were measured weekly from 6 April to 28 April. The plant height, number of nodes, diameter of stem, and leaf area were measured at 1 June, 2016.

\section{Statistical Analysis}

Data were analyzed by one-way analysis of variance (ANOVA) using the SAS program (Statistical Analysis System, 9.2 Version, SAS Institute, Cary, NC, USA). Treatment means were compared using LSD test at $p<0.05$ for greenhouse experiment and t-test at $p<0.05$. Graphs were generated with Sigmaplot 11 (Systat software Inc., CA, USA).

\section{Results}

\section{Spectral Characteristics of Light Sources}

The spectral characteristics of HPS and SP were measured in the growth chambers. SP has a more similar light spectrum to the sunlight than HPS which has two peaks around $550 \sim 650 \mathrm{~nm}$ and $800 \sim 820 \mathrm{~nm}$ (Fig. 3) and showed 1.3 and 4.7 times higher in PAR and UV ratios, and 17.0 and 1.3 times lower in NIR and R/FR ratios than HPS (Table 1). SP showed the R/FR ratio closer to sunlight than HPS. The photon flux sum of R and FR (Myers, 1971) in SP was 1.3 times higher than that in HPS.

In addition, light spectra in the greenhouses were measured before sunrise, after sunset, on a cloudy day, and at night on 2 March, 2016 (Fig. 4). Regardless of different solar radiation conditions after sunrise, before sunset, and on cloudy days, the light intensities were very low at that time and shown as similar spectra patterns to those observed in the growth chambers. 
Comparing Photosynthesis, Growth, and Yield of Paprika (Capsicum annuum L. 'Cupra') under Supplemental Sulfur Plasma...

Table 1. Spectral characteristics of high pressure sodium lamp (HPS) and sulfur plasma lamp (SP).

\begin{tabular}{ccc}
\hline \hline Specification & HPS & SP \\
\hline PPFD $\left(\mu \mathrm{mol} \cdot \mathrm{m}^{-2} \cdot \mathrm{s}^{-1}\right)$ & 1850 & 1444 \\
PPFD / Watt $\left(\mu \mathrm{mol} \cdot \mathrm{m}^{-2} \cdot \mathrm{s}^{-1} \cdot \mathrm{W}^{-1}\right)$ & 1.85 & 1.40 \\
$\mathrm{UV}(300-400 \mathrm{~nm})$ ratio $(\%)$ & 0.03 & 0.14 \\
PAR $(400-700 \mathrm{~nm})$ ratio $(\%)$ & 23.40 & 30.65 \\
NIR $(700-1100 \mathrm{~nm})$ ratio $(\%)$ & 56.05 & 3.29 \\
Red (655-665 nm) / Far-red $(725-735 \mathrm{~nm}), \mathrm{R} / \mathrm{FR}$ & 2.96 & 2.09 \\
Sum of Red and Far-red $\left(\mathrm{R}+\mathrm{FR}, \mu \mathrm{mol} \cdot \mathrm{m}^{-2} \cdot \mathrm{s}^{-1}\right)$ & 3.70 & 4.87
\end{tabular}

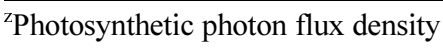

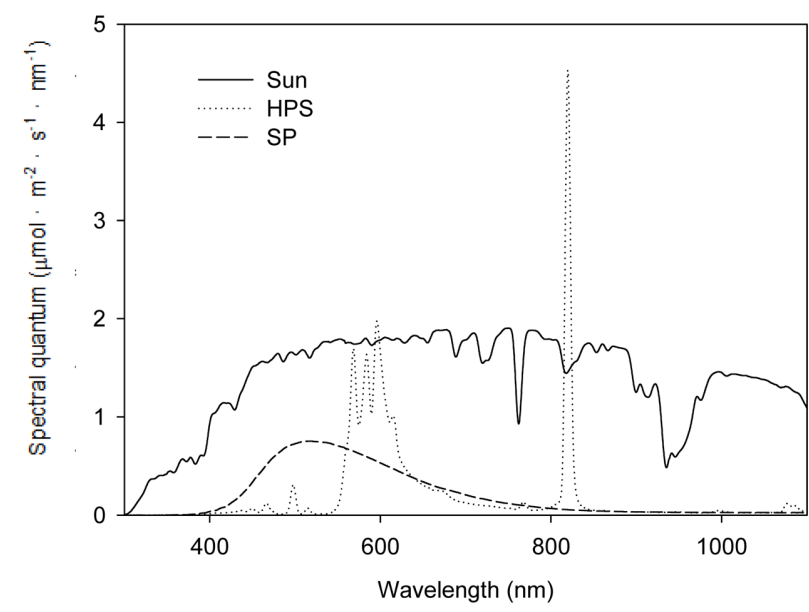

Fig. 3. Spectral quantum distributions of sunlight (Sun, 11:00 on 2 March, 2016), high-pressure sodium lamp (HPS), and sulfur plasma lamp (SP) used in the growth chamber.

\section{Growth and Photosynthesis at SP and HPS as Main Lights in the Growth Chamber}

The plant height, leaf area, leaf fresh weight, and leaf dry weight at SP in the growth chambers were significantly higher than those at HPS, while the stem diameter, number of leaves, SPAD, stem fresh weight, and stem dry weight were not significantly different on 27 June, 2016 (Table 2). In particular, SP significantly enhanced the leaf area by $29 \%$ as compared to HPS and also induced a higher plant height, leaf area, and dry weight than HPS during the growth period in the growth chamber (Fig. 5). In particular, the plant height and dry weight were significantly higher at SP than HPS all the time on 27 June (Figs. 5A, 5C). The leaf areas at SP and HPS showed similar patterns until 12 June, 2016; however, the rate of leaf area at HPS decreased afterwards (Fig. 5B). The photosynthetic rate was significantly higher at SP than

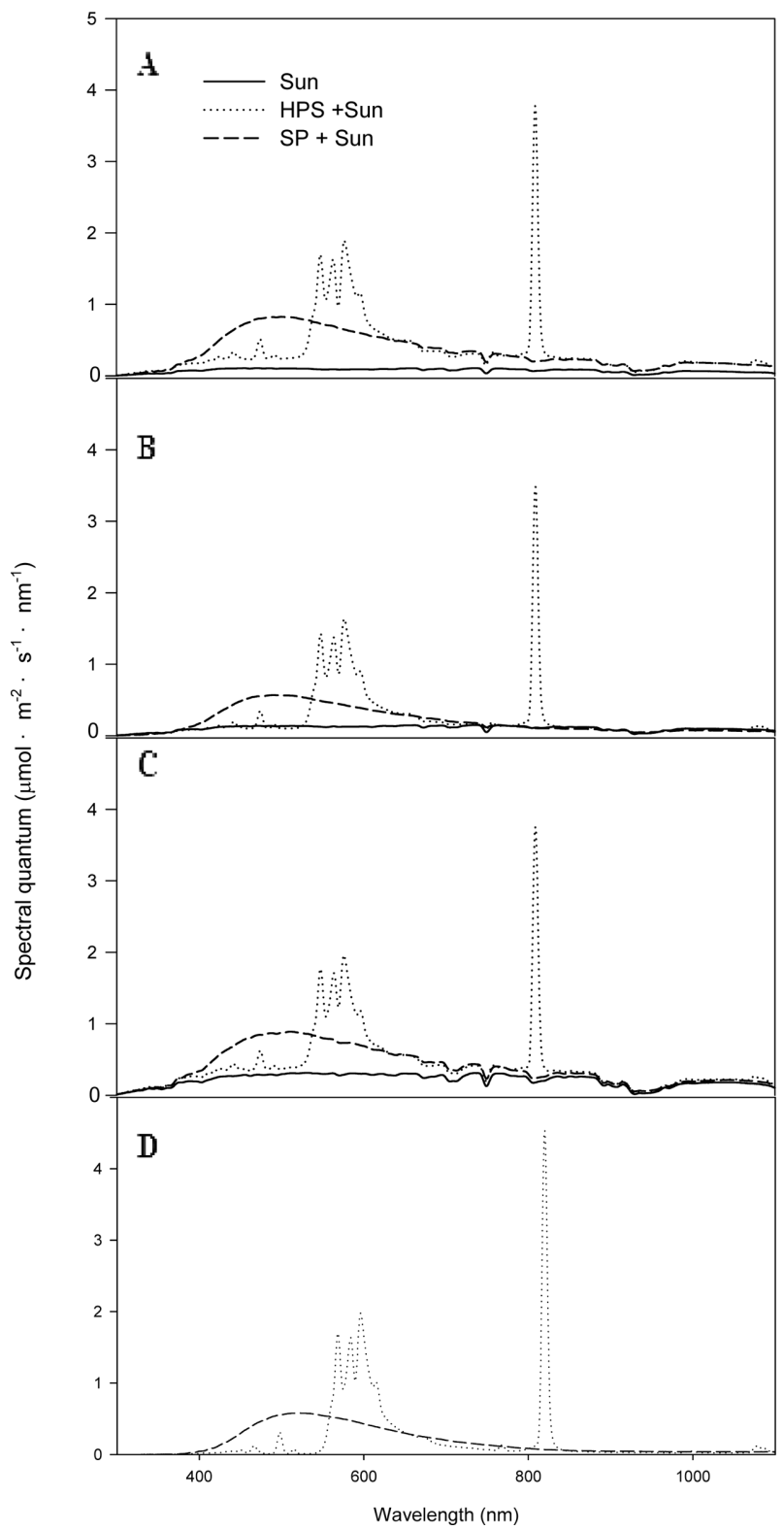

Fig. 4. Spectral quantum distributions with time in the greenhouses under sunlight with no supplemental lighting (Sun), sunlight with high-pressure sodium lamp (Sun + HPS), and sunlight with sulfur plasma lamp (Sun + SP): (A) before sunrise, (B) after sunset, (C) cloudy day, and (D) midnight on 2 March, 2016.

that at HPS on 16 June (Fig. 6). Below the PPFD of $300 \mu \mathrm{mol} \cdot \mathrm{m}^{-2} \cdot \mathrm{s}^{-1}$, the photosynthetic rate was similar between SP and HPS; however, afterwards it became significantly higher at SP (Fig. 6A). The stomatal conductance and transpiration rate showed similar tendencies to the photosynthetic rate, showing increases at SP and decreases at HPS with increase of PPFD (Figs. 6B, 6C). 
Kyoung Sub Park, Dae Young Kwon, Joon Woo Lee, and Jung Eek Son

Table 2. Growth indexes and chlorophyll contents of paprika $(n=5)$ grown under high-pressure sodium lamp (HPS) and sulfur plasma lamp (SP) in the growth chamber (on 27 June, 2016).

\begin{tabular}{|c|c|c|c|c|c|c|c|c|c|c|c|}
\hline \multirow{2}{*}{$\begin{array}{c}\text { Light } \\
\text { source }\end{array}$} & \multirow{2}{*}{$\begin{array}{l}\text { Plant } \\
\text { height } \\
(\mathrm{cm})\end{array}$} & \multirow{2}{*}{$\begin{array}{c}\text { Stem } \\
\text { diameter } \\
(\mathrm{cm})\end{array}$} & \multirow{2}{*}{$\begin{array}{l}\text { No. of } \\
\text { leaves } \\
\text { (ea) }\end{array}$} & \multirow{2}{*}{$\begin{array}{l}\text { Leaf } \\
\text { area } \\
\left(\mathrm{cm}^{2}\right)\end{array}$} & \multirow{2}{*}{$\begin{array}{l}\text { Chlorophyll } \\
\text { Content } \\
\text { (SPAD) }\end{array}$} & \multicolumn{3}{|c|}{ Fresh weight (g) } & \multicolumn{3}{|c|}{ Dry weight (g) } \\
\hline & & & & & & Leaf & Stem & Total & Leaf & Stem & Total \\
\hline HPS & $48.8^{\mathrm{z}}$ & 11.3 & 40.5 & 3862.6 & 62.7 & 178.9 & 79.0 & 257.9 & 17.0 & 8.1 & 23.0 \\
\hline SP & 57.5 & 10.5 & 43.0 & 4976.9 & 60.7 & 194.2 & 79.7 & 273.9 & 18.5 & 7.8 & 26.4 \\
\hline Significane $^{y}$ & $*$ & NS & NS & $* *$ & NS & * & NS & NS & $*$ & NS & NS \\
\hline
\end{tabular}

${ }^{\mathrm{z}}$ Mean separation in columns according to t-test $(p<0.05)$.

${ }^{y} \mathrm{NS}$, not significant; *, ** significant at $p=0.05$ or 0.01 .

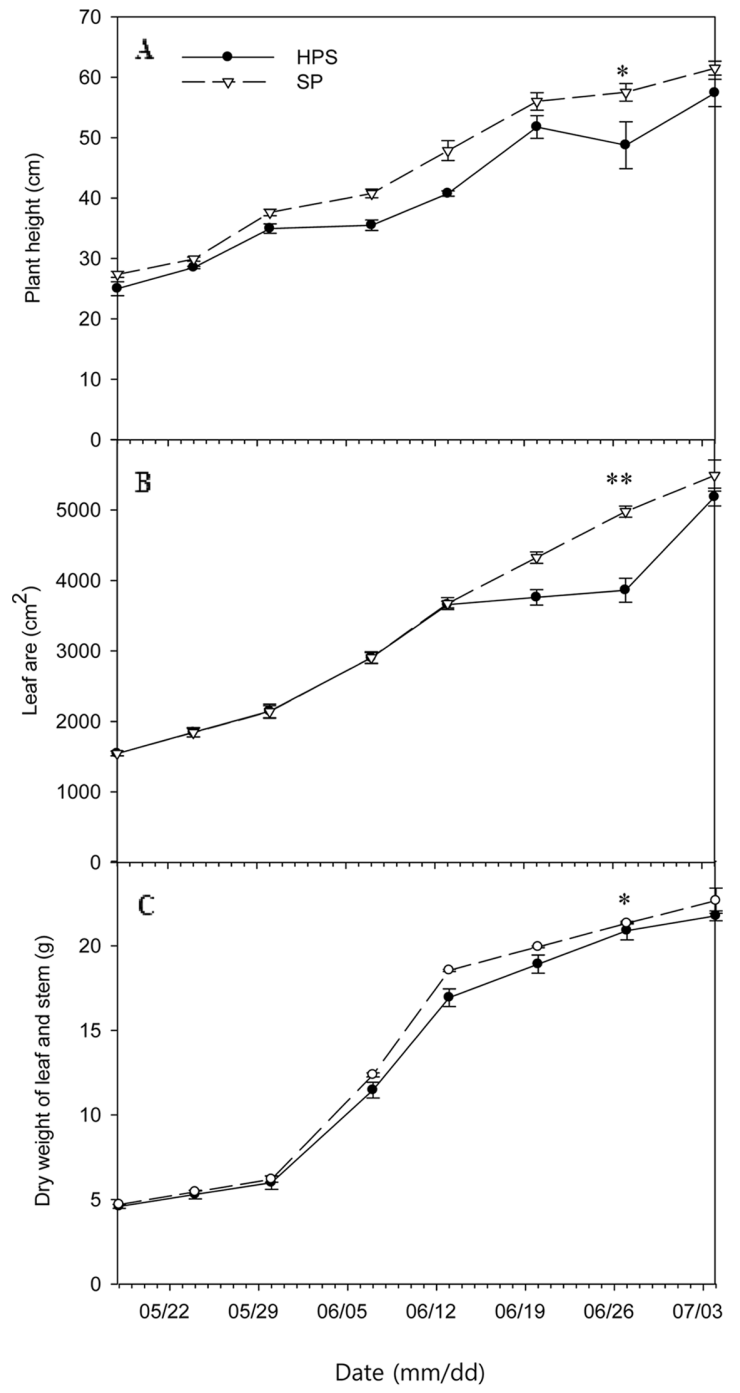

Fig. 5. Changes in plant height (A), leaf area (B), and dry weight (C) of paprika grown under high-pressure sodium lamp (HPS) and sulfur plasma lamp (SP) in the growth chamber (from 18 May to 5 July, 2016). Vertical bars represent the standard error of the mean $(\mathrm{n}=5) . *, * *$ show significance at $p=0.05$ or 0.01 according to t-test on 27 June, respectively.

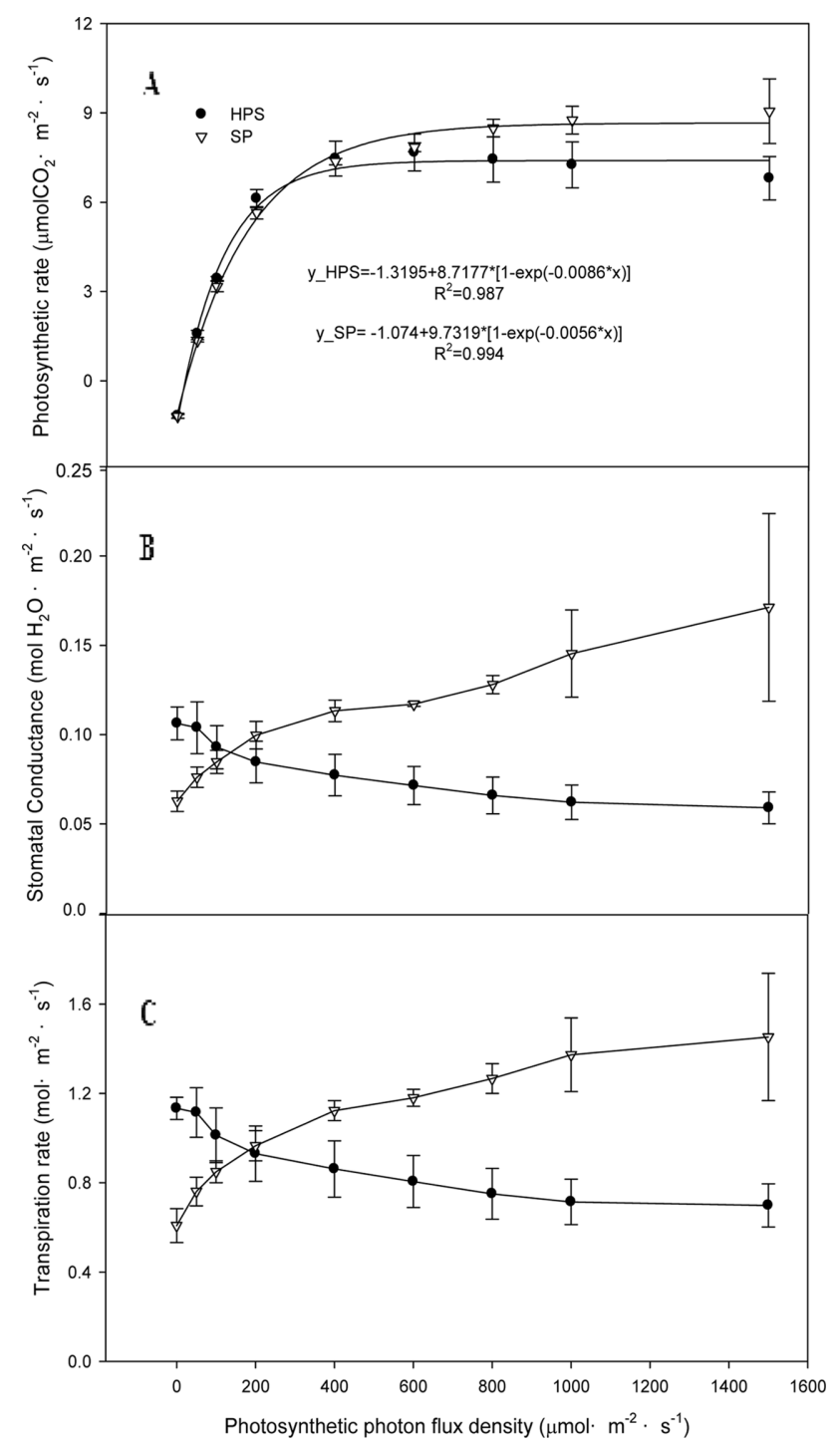

Fig. 6. Photosynthetic rate (A), stomatal conductance (B), and transpiration rate $(\mathrm{C})$ of paprika grown under high- pressure sodium lamp (HPS) and sulfur plasma lamp (SP) in the growth chamber. Vertical bars represent the standard error of the mean $(n=3)$. 
Comparing Photosynthesis, Growth, and Yield of Paprika (Capsicum annuum L. 'Cupra') under Supplemental Sulfur Plasma...

Table 3. Growth indexes of paprika $(n=3)$ grown under sunlight with no supplemental lighting (Sun), sunlight with the high-pressure sodium lamp (Sun + HPS), and sunlight with the sulfur plasma lamp (Sun + SP) in the greenhouses on 1 June, 2016.

\begin{tabular}{ccccc}
\hline \hline $\begin{array}{c}\text { Light } \\
\text { source }\end{array}$ & $\begin{array}{c}\text { Plant height } \\
(\mathrm{cm})\end{array}$ & $\begin{array}{c}\text { Stem diameter } \\
(\mathrm{cm})\end{array}$ & $\begin{array}{c}\text { No. of nodes } \\
(\mathrm{ea})\end{array}$ & $\begin{array}{c}\text { Leaf area } \\
\left(\mathrm{cm}^{2}\right)\end{array}$ \\
\hline Sun & 186.4 & $17.5 \mathrm{~b}^{\mathrm{z}}$ & 50.8 & 6235.2 \\
Sun + HPS & 173.4 & $18.5 \mathrm{a}$ & 47.3 & 5891.2 \\
Sun + SP & 182.4 & $18.2 \mathrm{ab}$ & 52.5 & 5867.5 \\
Significance & NS & $*$ & NS & NS \\
\hline
\end{tabular}

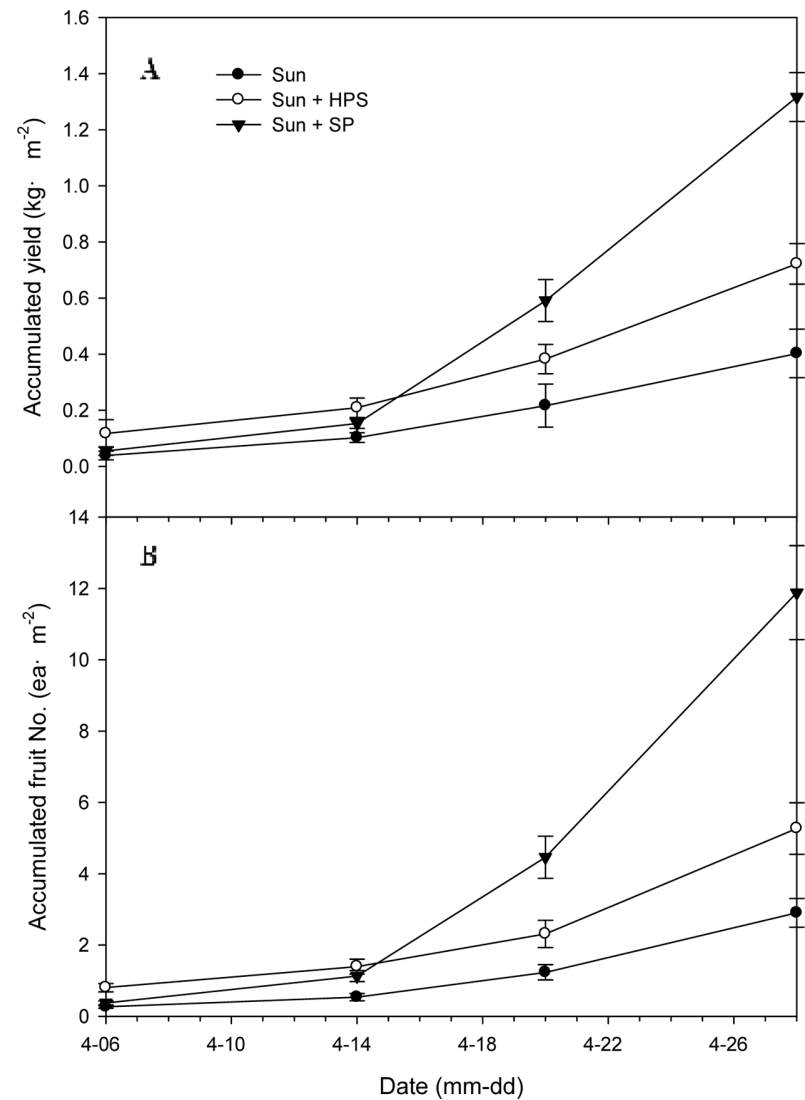

Fig. 7. Accumulated yields $\left(\mathrm{A}, \mathrm{kg} \cdot \mathrm{m}^{-2}\right)$ and fruit numbers of paprika fruits $\left(\mathrm{B}, \mathrm{ea} / \mathrm{m}^{2}\right)$ grown under sunlight with no supplemental lighting (Sun), sunlight with high-pressure sodium lamp (Sun + HPS), and sunlight with sulfur plasma lamp (Sun + SP) in the greenhouses from 6 to 28 April, 2016. Vertical bars represent the standard error of the mean $(n=3)$.

\section{Yield and Fruit Number of Paprika at SP and HPS as Supplemental Lights in the Greenhouses}

In greenhouse, the stem diameter was significantly bigger at Sun + HPS and Sun + SP treatments than at Sun (Table 3). The accumulated yield and number of fruits were significantly higher at Sun + HPS and Sun + SP than at Sun (Fig. 7). Specifically, there were $79 \%$ and $227 \%$ higher in accumulated yields (Fig. 7A) and $81 \%$ and $309 \%$ higher in numbers of fruits, respectively, at Sun + HPS and Sun + SP than at Sun from 6 April, 2016 (DAT 119) to 28 April, 2016 (DAT 147) when supplemental lighting affected the growth of the plants (Fig. 7B). Consequently, the number of fruits and weight of fruits were higher at SP than at HPS. Considering the difference in amount of fruits, the yield of paprika per energy was higher at SP than at HPS.

\section{Discussion}

\section{Growth and Photosynthesis at SP and HPS as} Main Light in the Growth Chamber

The growth indices of paprika was stimulated by SP than HPS and the individual leaf area increased at SP in the growth chamber. Active phytochrome activated by red light, such as supplemental lamps like SP and HPS, increased plant growth as a result of increased photosynthetic rates. The ratio and $\mathrm{R}$ and FR in the sunlight on clear days was calculated as 1.09 (Smith, 1982). In this study, the ratio at SP showed closer to that on clear days than at HPS. It means that SP stimulated photosynthesis than HPS and active photosynthesis transferred growth signal by active phytochrome (Paul, 2016).

The higher photon flux sum of R and FR at SP than HPS, the more stimulated the improvement of photosynthesis by Emerson effect (Myers, 1971). In particular, SPs have widely spectral characteristics that stimulated the plant height due to more red wavelengths and smaller R/RF ratio like the sunlight. Furthermore, these results may come from higher photosynthetic rates of paprika grown at SP than HPS lamp in the growth chamber due to the high stomatal conductance and transpiration rate of paprika grown at SP. Light quality had no impact on the initial slope of the $\mathrm{CO}_{2}$ response curve in our results, while the temperature could influence the initial slope (Sage and Sharkey, 1987; Sager et al., 1989; Sharkey et al., 2017). Since the initial slope was Pepindetermined by the Rubisco activity (von 
Caemmerer and Farquhar, 1981), this indicated that the plant treated with high light limited the Rubisco activity. Photoreceptors, such as phytochromes, phototropins, and cryptochromes, are involved in physiological responses, such as stomatal density or size of aperture and photosynthesis characteristics, and these are affected by light quality (Hogewoning et al., 2010a, 2010b; Amoozgar et al., 2017). The blue wavelength has been reported to increase stomatal opening and improve gas exchange for photosynthesis (Kinoshita et al., 2001). The higher blue band spectrums found in the plasma lamps can have a greater effect on the light saturation and compensation point (Fig. 6A).

\section{Yield and Fruit Number of Paprika at SP and HPS as Supplemental Light in the Greenhouses}

Previous research reported that the yield of tomato increased with the increase in the amount of light received from flowering to harvest (McAvoy et al., 1989). When the light level on the top of the canopy or within the canopy was low, application of supplemental lighting at the top of the canopy or within the canopy enhanced the yield of tomatoes and other vegetable species (McAvoy et al., 1989; Hovi et al., 2004; Pettersen et al., 2010). The results of the present study are consistent with these findings.

In this study, supplemental lighting was applied from 1 March, 2016 to 1 June, 2016 for three months because the supplemental lighting effect drastically decreased after 1 May, 2016 due to longer day length. Therefore yield data were collected from one month after the treatment to before May, 2016 as pure results of three-month supplemental lighting because the yield was somewhat affected by previous sunlight condition for one month after 1 March, 2016 and was little affected by the supplemental lighting after 1 May, 2016. With supplemental lightings, the growth and yield were enhanced than those without supplemental lighting (Fig. 6). In the greenhouse, the yield of paprika was higher at the supplemental lightings than in the control.

Many studies have reported that individual wavelengths can differentially affect fruit production ( $\mathrm{Li}$ and Kubota, 2009; Hogewoning, 2010a, 2012; Hikosaka et al., 2013; Guo et al., 2016a, 2016b; Hao et al., 2016; Amoozgar et al., 2017; Yang et al., 2017). For example, Pepin et al. (2014) suggested that tomato crop yield may be achieved by providing supplemental LED lighting within the plant canopy under low natural light conditions. Also, application of plasma emitting lights produced a $5.5 \%$ increase in dry matter with a $13 \%$ increase in fruit number of paprika (Lee et al., 2014). In addition, tomato plants under plasma lighting also had more consistent fruit size with a higher nutritional value and better taste (data not shown). Since plasma light has more ultra violet wavelengths and less yellow and red light than HPS, this can impact the biochemical metabolites in fruits.

The supplemental lighting is an effective method of enhancing crop growth and yield. Considering that our experiments started from March to April, 2016, the cultivation conditions rapidly improved with the increase of solar radiation and air temperature. As the supplemental lighting promoted the physiological activities of the plants, adequate fertigation might be adjusted to meet the increased requirements. Despite this condition, the results indicate that supplemental lighting, particularly SP, could a proper artificial light source. SP showed a light spectrum similar to sunlight, higher PAR and photon flux sum of red and far-red wavelengths than HPS, which increased the photosynthesis and yield of paprika. Further studies are needed to investigate the fertigation system control adapted to supplemental lighting.

\section{Acknowledgements}

This study was supported by ICT project (PJ0121002017) of National Institute of Horticultural \& Herbal Science, Rural Development Administration, Republic of Korea.

\section{Literature Cited}

Aistè, B., B. Aušra, V. Akvilè, S. Giedrè, J. Julè, S. Ramūnas, S. Sandra, M. Jurga, and M. Nijolè. 2015. Cultivation of sweet pepper (Capsicum annuum L.) transplants under high pressure sodium lamps supplemented by light-emitting diodes of various wavelengths. Acta Sci. Pol. Hortorum Cultus 14:3-14.

Amoozgar, A., A. Mohammadi, and M.R. Sabzalian. 2017. Impact of light-emitting diode irradiation on photosynthesis, phytochemical composition and mineral element content of lettuce cv. Grizzly. Photosynthetica 55:85-95.

Cocetta, G., D. Casciani, R. Bulgari, F. Musante, A. Kolton, M. Rossi, and A. Ferrante. 2017. Light use efficiency for vegetables production in protected and indoor environments. Eur. Phys. J. Plus. 132:43.

Demers, D.A., M. Dorais, C.H. Wien, and A. Gosselin. 1998. Effects of supplemental light duration on greenhouse tomato 
Comparing Photosynthesis, Growth, and Yield of Paprika (Capsicum annuum L. 'Cupra') under Supplemental Sulfur Plasma...

plants and fruit yields. Sci. Hortic. 74:295-306.

de Visser, P.H.B., G.H. Buck-Sorlin, G.W. and van der Heijen. 2014. Optimizing illumination in the greenhouse using a 3D model of tomato and a ray tracer. Front. Plant Sci. 5:48.

Dorais, M., A. Gosseelin, and M.J. Trudel. 1991. Annual greenhouse tomato production under a sequential intercropping system using supplemental light. Sci. Hortic. 45: 225234.

Gomez, C., R.C. Morrow, M. Bourget, G. Massa, and C.A. Michell. 2013. Comparison of intracanopy light-emitting diode towers and overhead high-pressure sodium lamps for supplemental lighting of greenhouse-grown tomatoes. HortTechnology 23:93-98.

Guo, X., X. Hao, J.M. Zheng, C. Little, and S. Khosla. 2016a. Effects of plasma vs. high-pressure sodium lamps on plant growth, fruit yield and quality in greenhouse cucumber production. Acta Hortic. 1134:79-86.

Guo, X., X. Hao, J.M. Zheng, C. Little, and S. Khosla. 2016 b. Response of greenhouse mini-cucumber to different vertical spectra of LED lighting under overhead high-pressure sodium and plasma lighting. Acta Hortic. 1134:87-94.

Hao, X., C. Little, J.M. Zheng, and R. Cao. 2016. Far-red LEDs improve fruit production in greenhouse tomato grown under high-pressure sodium lighting. Acta Hortic. 1134:95102.

Hao, X. and A.P. Papadopoulos. 1999. Effects of supplemental lighting and cover materials on growth, photosynthesis, biomass partitioning, early yield and quality of greenhouse cucumber. Sci. Hortic. 80:1-18.

Hernández, R. and C. Kubota. 2014. Growth and morphological response of cucumber seedlings to supplemental red and blue photon flux ratios under varied solar daily light integrals. Sci. Hortic. 173:92-99.

Hikosaka, S., S. Iyoki, M. Hayakumo, and E. Goto. 2013. Effects of light intensity and amount of supplemental LED lighting on photosynthesis and fruit growth of tomato plants under artificial conditions. J. Agric. Meteorol. 69: 93-100.

Heuvelink, E. and O. Korner. 2001. Parthenocarpic fruit growth reduces yield fluctuation and blossom-end rot in sweet pepper. Ann. Bot. 88:69-74.

Hogewoning, S.W., P. Douwstra, G. Trouwborst, W. van Ieperen, and J. Harbinson. 2010a. An artificial solar spectrum substantially alters plant development compared with usual climate room irradiance spectra. J. Exp. Bot. 61:1267-1276.

Hogewoning, S.W., P. Douwstra, G. Trouwborst, W. van Ieperen, and J. Harbinson. 2010b. Blue light dose-responses of leaf photosynthesis, morphology, and chemical composition of Cucumis sativas grown under different combinations of red and blue light. J. Exp. Bot. 61:3107-3117.

Hogewoning, S.W., G. Trouwborst, E. Meinen, and W. van Ieperen. 2012. Finding the optimal growth-light spectrum for greenhouse crops. Acta Hortic. 956:357-364.

Hovi, T., J. Näkkilä, R. Tahvonen. 2004. Interlighting improves production of year-round cucumber. Sci. Hortic. 102:283-294.

Jeong, W.J., J.H. Lee, H.C. Kim, and J.H. Bae. 2009a. Dry matter production, distribution and yield of sweet pepper grown under glasshouse and plastic greenhouse in Korea. J. Bio-environ. Cont. 18:255-265 (in Korean).

Jeong, W.J., D.J. Myung, and J.H. Lee. 2009b. Comparison of climatic conditions of sweet pepper's greenhouse between Korea and the Netherlands. J. Bio-environ. Cont. 18:244252 (in Korean).

Kim, E.J., S.H. Lee, and J.H. Lee. 2013. Effects of the high pressure sodium lamp lighting on the dynamics of growth and dry mass partitioning in sweet pepper plant. Korean J. Hortic. Sci. Technol. 31:565-572 (in Korean).

Kim, Y.B., J.H. Bae, and M.H. Park. 2011. Effects of supplemental lighting on growth and yield of sweet pepper (Capsicum annuum L.) in hydroponic culture under low levels of natural light in winter. Korean J. Hortic. Sci. Technol. 29:317-325 (in Korean).

Kinoshita, T., M. Doi, N. Suetsugu, T. Kagawa, M. Wada, and K. Shimazaki. 2001. phot1 and phot2 mediate blue light regulation of stomatal opening. Nature 414: 665-660.

Lee, J.W., H.C. Kim, P.H. Jeong, Y.G. Ku, and J.H. Bae. 2014. Effects of supplemental lighting of high-pressure sodium and lighting emitting plasma on growth and productivity of paprika during low radiation period of winter season. Korean J. Hortic. Sci. Technol. 32:346-352 (in Korean).

Li, Q. and C. Kubota. 2009. Effects of supplemental light quality on growth and phytochemicals of baby leaf lettuce. Environ. Exp. Bot. 67:59-64.

Mcavoy, R.J., H.W. Janes, B.L. Godfriaux, M. Secks, D. Duchai, and W.K. Wittman. 1989. The effect of total available photosynthetic photon flux on single truss tomato growth and production. J. Hortic. Sci. 64:331-338.

Myers, J. 1971. Enhancement studies in photosynthesis. Ann. Rev. Plant Physiol. 22:289-312.

Paul, F.D. 2016. Plants wait for the lights to change to red. PNAS. 113:7301-7303.

Pepin, S., E. Fontier, S.A. Bechard-Dube, M. Dorais, C. Menard, and R. Bacon. 2014. Beneficial effects of using a 3-D LED interligting system for organic. Acta Hortic. 1041:239-246.

Pettersen, R.I., S. Torre, and H.R. Gislerød. 2010. Effects of intracanopy lighting on photosynthetic characteristics in cucumber. Sci. Hortic. 125:77-81.

Sage, R.F. and T.D. Sharkey. 1987. The effect of temperature on the occurrence of $\mathrm{O}_{2}$ and $\mathrm{CO}_{2}$ insensitive photosynthesis in field grown plants. Plant Physiol. 84:658-664.

Sage, R.F., T.D. Sharkey, and J.R. Seemann. 1989. Acclimation of photosynthesis to elevated $\mathrm{CO}_{2}$ in five $\mathrm{C} 3$ species. Plant Physiol. 89:590-596.

Sharkey, T.D., C.J. Bernacchi, G.D. Farquar, and E.L. Singsaas. 2007. Fitting photosynthetic carbon dioxide response 
curves for C3 leaves. Plant Cell Environ. 30:1035-1040.

Smith, H. 1982. Light quality, photoperception, and plant strategy. Ann. Rev. Plant Physiol. 33:481-518.

Trouwborst, G., J. Oosterkamp, S.W. Hogewoning, J. Harbinson. 2009. The responses of light interception, photosynthesis and fruit yield of cucumber to LED-lighting within the canopy. Physiol. Planta 138:289-300.

von Caemmerer, S. and G.D. Farquhar. 1981. Some relation- ships between the biochemistry of photosynthesis and the gas exchange of leaves. Planta 153:376-387.

Yang, L.Y., L.T. Wang, J.H. Ma, E.D. Ma, J.Y. Li, and M. Gong. 2017. Effects of light quality on growth and development, photosynthetic characteristics and content of carbohydrates in tobacco (Nicotiana tabacum L.) plants. Photosynthetica 55:467-477.

\title{
황 플라즈마 및 고압나트륨 램프의 보광에 따른 생육상 및 온실에서의 파프리카 광합성 및 생산성 비교
}

\author{
박경섭 ${ }^{1 \dagger} \cdot$ 권대영 ${ }^{\dagger}$. 이준우 ${ }^{3} \cdot$ 손정익 $^{3 *}$ \\ 1국립원예특작과학원 시설원예연구소, ${ }^{2}$ 청주농업기술센터, \\ 3서울대학교 식물생산과학부 및 농업생명과학연구원
}

\begin{abstract}
적 요. 인공광을 이용한 보광은 시설재배에서 작물의 정상적인 생육과 수확량을 유지하고 품질 향상을 위하 여 사용되는 실용적인 방법이다. 본 연구의 목적은 황 플라스마 램프(SP)와 고압 나트륨 램프(HPS)의 보광이 파프리카의 생육 및 수확량에 미치는 영향을 조사하는 것이다. 생장상에서는 SP 및 HPS를 기본 광원으로, 온 실에서는 보광으로 사용하여 작물 생육에 미치는 효과를 비교 분석하였다. 생장상에서는 정식 2 주 후 $\mathrm{SP}$ 와 HPS 하에서 초장, 엽면적, 줄기 직경, 엽수, 생체중 및 건물중을 매주 측정 하였다. 온실재배에서는 무보광을 대조구로 하였다. 보광은 07:00부터 21:00까지 외부일사 $100 \mathrm{~W} \cdot \mathrm{m}^{-2}$ 미만일 때 처리되도록 하였다. 보광 처리 후 3 주부터 매주 생육량을 측정하였고, 2 주 마다 수확하여 과실수와 과실무게를 측정하였다. 생장상에서는 높은 광합성속도로 인하여 SP가 HPS보다 생육이 양호하였고, 온실에서는 보광처리가 대조구보다 수확량이 유의적 으로 높았다. 온실에서의 초장, 마디수, 엽장, 생체중, 건물중은 SP와 HPS 간의 유의적인 차이는 없었다. 그러 나 수확 시 과실수와 수량은 광합성 증진과 및 과실수의 증가로 인하여 $\mathrm{SP}$ 에서 많았다. $\mathrm{SP}$ 는 태양광과 유사한 광 스펙트럼을 보였으나, HPS와 비교하여 높은 PAR과 적색과 원적색 파장의 광양자속의 합이 높았기 때문에 파프리카의 광합성과 수확량을 증가시켰다.
\end{abstract}

추가주제어: 온실, 생육상, 황플라즈마등, 고압나트륨등, 태양광, 보광 